\title{
EDITORIAL
}

\section{Memória de minhas relações com Paulo Freire}

\author{
Ubiratan D’Ambrosio* \\ ORCID iD 0000-0003-0564-158X
}

\section{Uma introdução explanatória}

Conheci Paulo Freire somente na década de 80, quando ele foi contratado pela Universidade Estadual de Campinas (UNICAMP).

Em 1950, iniciei minha formação acadêmica em Matemática Pura, cursando Bacharelado e Licenciatura na Faculdade de Filosofia, Ciências e Letras da Universidade de São Paulo (USP - Rua Maria Antônia). Enquanto ainda aluno, comecei a lecionar com um certificado provisório, que era comum na época. Fui um professor tradicional, propondo muitas inovações na minha prática. Durante o curso, tive a disciplina Didática Geral, Didática Especial da Matemática e Psicologia Experimental. Todas com tratamento tradicional, bem atualizadas.

A disciplina Didática Geral abordava, essencialmente, História e Filosofia da Educação. O momento político da década de 1950 foi agitado. Em plena Guerra Fria, começou a Guerra da Coréia, que se prolongou. Surgiram movimentos revolucionários em toda a América Latina, contestando o imperialismo e combatendo, com guerrilhas de orientação esquerdista, governos estabelecidos, muitos dominados por militares e por governos corruptos. Muitos movimentos de inovação política tinham como foco a situação do homem do campo, analfabetismo e injustiça social. Ao mesmo tempo, o mundo atravessava

\footnotetext{
* Doutor em Matemática pela Universidade de São Paulo (USP). Professor Emérito da Universidade Estadual de Campinas (UNICAMP), Campinas, São Paulo, Brasil. Professor credenciado ao Programa de Pós-Graduação em Educação Matemática da Universidade Estadual Paulista (UNESP), Rio Claro, São Paulo, Brasil. E-mail: ubi@usp.br.
} 
um período de grande desenvolvimento científico e tecnológico, sobretudo nas comunicações, com o surgimento da televisão.

No Brasil, a luta sob a bandeira "o petróleo é nosso" atingiu fortemente todos os setores da sociedade. A morte de Getúlio Vargas, em 1954, criou um clima de reforma com a eleição de Juscelino Kubistchek e a construção de Brasília, intensificando os movimentos para a reforma agrária e a alfabetização em massa, principalmente das populações rurais. A intensificação da Guerra Fria entre Estados Unidos e URSS e o sucesso da Revolução Cubana, em 1959, sob liderança de Fidel Castro, estimulou, no início na década de 1960, uma série de conflitos na América Central, por grupos armados conhecidos como guerrilheiros, que se prolongaram por três décadas.

Inicialmente na Guatemala, Honduras, Nicarágua e El Salvador, esses movimentos surgiram como uma reação às ditaduras militares e governos autocráticos de direita conservadora, implantados ou apoiados pelos Estados Unidos para proteger os seus interesses geopolíticos. A estrutura da organização da guerrilha foi além das fronteiras da América Central, atingindo praticamente toda a América Latina. Com intenções semelhantes, diferentes países tentaram eliminar os movimentos insurgentes, que tinham características muito diferentes. Muito importante foi a emergência de ditaduras militares em vários países.

Durante todo esse período, eu completava meus estudos de Matemática Pura para chegar ao doutorado, em 1963. Eu acompanhava, com atenção, tudo que se passava nos vários países e a emergência de conflitos no Brasil entre grupos progressistas, inclusive no governo, então tendo João Goulart como Presidente da República, e a reação da sociedade civil conservadora, apoiada por militares. A tensão tornava-se crescente. Eram muito comentadas as inovações e avanços políticos em Pernambuco, sob liderança do Governador Miguel Arraes. Seu apoio às Ligas Camponesas que, lideradas por Francisco Julião, apareciam como a maior instância de contestação aos latifúndios. Confesso que, até então, jamais ouvira falar em Paulo Freire, embora se comentasse sobre propostas inovadores na alfabetização, no campo, de jovens e adultos.

Terminando o doutorado, em 1963, fui imediatamente convidado pelo Prof. Wendell H. Fleming, da Brown University (Providence RI, Estados Unidos), para passar um ano como Research Associate no grupo de Teoria Geométrica da Medida. Com um salário razoável, viagem paga (inclusive para a família), aceitei, muito feliz, o convite. Ingressei num excelente grupo de pesquisa, reconhecido internacionalmente, e um ambiente acolhedor, de alto nível. Do ponto de vista de família, eu, esposa e filhos fomos recebidos e apoiados de uma forma memorável e inesquecível. Em abril de 1964, recebemos a notícia do Golpe Militar no Brasil. 
Meus colegas da Brown acharam que eu não deveria voltar para o Brasil e renovaram meu contrato como Research Associate por mais um ano. A situação no Brasil piorou, com vários exilados, e foi prudente não voltar.

Os colegas da Brown me ajudaram a encontrar um excelente emprego, na recémfundada State University of New York at Buffalo (SUNYaB). Era um ambiente cientificamente de vanguarda. Ali, tive como colega Abdias do Nascimento, com quem desenvolvi grande amizade. Permaneci na SUNYaB até 1972, quando recebi um convite tentador do Professor Zeferino Vaz, que havia fundado, em 1968, a UNICAMP. Zeferino logrou, mediante acordo com os militares, criar uma universidade de altíssimo nível, com muitos recursos. Zeferino Vaz, que havia sido uma liderança política no Golpe Militar, convenceu os militares que para construir uma universidade de alto nível era necessário atrair brasileiros que haviam sido exilados ou autoexilados no exterior após o Golpe Militar.

Assim, inúmeros brasileiros em posição de destaque nos Estados Unidos, Europa e outros países retornaram para a UNICAMP. A UNICAMP tornou-se uma área acadêmica ideologicamente aberta e acolhedora para todas as correntes filosóficas e políticas, e protegida de interferência militar. De fato, era a única universidade brasileira sem um gabinete militar associado/controlando a reitoria. Voltar ao Brasil, nessas condições, foi uma decisão acertada, não só do ponto de vista acadêmico, mas também pessoal e familiar. Logo assumi a direção do Instituto de Matemática, Estatística e Ciência da Computação (IMECC), onde permaneci como Diretor até 1980, sendo, logo depois, nomeado para uma posição que se tornaria PróReitoria de Desenvolvimento Universitário.

Enquanto estava nos Estados Unidos, ouvi falar de um educador brasileiro, Paulo Freire, que havia sido exilado e que escreveu, em 1969, o livro Pedagogia do Oprimido, de grande sucesso e repercussão internacional. Mas, não tive oportunidade de saber qualquer coisa sobre Paulo Freire e nem ler o livro.

\section{Guiné-Bissau e UNICAMP}

Enquanto ainda trabalhando nos Estados Unidos, fui contratado pela Organização das Nações Unidas para a Educação, a Ciência e a Cultura (UNESCO), em 1970, para lecionar, como visitante frequente, em países da África. Meu relacionamento com a UNESCO foi muito intenso e continuou após meu retorno ao Brasil, com inúmeras missões, sobretudo na África e América Latina. 
Em meados da década de 1970, fui contratado pela UNESCO para avaliar as condições de desenvolvimento científico das cinco ex-colônias portuguesas: Moçambique, Angola, Cabo Verde, São Tomé e Príncipe e Guiné-Bissau. Todas muito interessantes, mas muito especial foi a visita a Guiné-Bissau.

Ao chegar a Guiné-Bissau, fui recebido pelas autoridades e posto em contato com a equipe de técnicos e especialistas que foram trabalhar no país logo após a independência. Desde a independência, Paulo Freire desenvolvia um programa de alfabetização inovador. A filosofia era fazer da alfabetização o instrumento ideal para o reconhecimento pelo povo de sua historicidade. Daí a insistência em fazer a alfabetização em crioulo, a língua nativa, o que viria a se tornar impraticável. A filosofia de educação, no período pós-colonial, está bem discutida em seu livro Cartas a Guiné-Bissau: registros de uma experiência em processo. Uma das frases que considero mais esclarecedora da filosofia de educação de Paulo Freire é:

\begin{abstract}
Uma experiência como esta - a de aprender primeiro para, ensinando depois, continuar a aprender - tínhamos tido, particularmente Elza e eu, no Chile, quando e onde, ao travar os primeiros encontros com educadores chilenos, escutávamos mais do que falávamos e, quando falávamos, era para descrever a prática que tivéramos no Brasil, com suas negatividades e suas positividades e não para prescrevê-la aos educadores chilenos (FREIRE, 1978, p. 12).
\end{abstract}

Vejo nessa frase a mesma filosofia de educador que ele expõe na sua tese de concurso de 1959:

Foi exatamente uma educação dessas [praticadas no SESI], que deve implicar num trabalho com o povo e nunca sobre o povo ou simplesmente para ele, através dos grupos, que tentamos realizar nossa comentada experiência. E é precisamente uma educação assim que, ultrapassando as paredes das escolas, precisa ser incrementada entre nós (FREIRE, 1959, p. 19).

Embora não tenha encontrado Paulo Freire na minha viagem a Guiné-Bissau, fui apresentado à equipe de especialistas que colaboravam na estruturação de uma nação. Foi muito prazeroso e de grande valia conhecer o economista Ladislau Dowbor e sua esposa, a educadora Fátima Freire, filha de Paulo Freire. Ajudaram-me a compreender a realidade econômica e prioridades para desenvolvimento e os avanços na educação dos países recémindependentes. Contaram-me sobre as ideias de Paulo Freire para alfabetização, principalmente a utilização do crioulo, a língua do povo, e seu desapontamento com propostas oficiais dando menor importância à linguagem popular. Consegui entender as dificuldades e resistências externas e internas no processo de sair do status da mentalidade colonizada, e de procurar novos caminhos. Foi então que conheci e comecei a ler as obras de Paulo Freire, que me encantaram e passaram a me acompanhar.

Uma curiosidade: andei no carro de Paulo Freire, que ele havia deixado com os filhos. 
Vários anos depois, em 1980, Paulo Freire foi contratado pela Faculdade de Educação da UNICAMP e, assim, nos encontramos pela primeira vez. Foi o início de uma amizade preciosa.

Na UNICAMP, eu frequentava seus seminários, sempre muito concorridos e estimulantes. O momento dos seminários era continuado, de forma descontraída e informal, no almoço, geralmente numa churrascaria na estrada para Paulínia, onde serviam uma rúcula fresquinha. Paulo adorava essa rúcula e daí os encontros ficarem conhecidos como clube da rúcula.

\section{Uma viagem decisiva e o ICME-8 em Sevilha}

Um momento de muita sorte para mim deu-se no início da década de 80. Viajei para os Estados Unidos para uma reunião na OEA (Organização dos Estados Americanos). Quando entrei no avião, minha grata surpresa foi ver que estava com assento ao lado de Paulo Freire. Nunca tive uma viagem tão gratificante.

Conversamos muito e tive a oportunidade de explicar para ele meu conceito de etnomatemática e entender claramente o significado social, político e humanitário que ele dava à alfabetização e à educação em geral. A partir dessa aproximação, que foram momentos prazerosos e construtivos, uma grande aula de educação e de humanidade, nosso relacionamento ficou mais intenso. Suas visitas e seminários na UNICAMP tornaram-se oportunidade de bons encontros e de aprofundar nossos pontos de vista.

Muito importante foi a oportunidade de ter participado, algumas vezes, e colaborado com o Movimento de Reorientação Curricular, uma proposta inovadora de Paulo Freire em sua gestão na Secretaria Municipal de Educação de São Paulo (1989-1991). O objetivo de sua proposta era dar a cada escola o direito de construir seu próprio currículo, ao invés de seguir as propostas emanadas dos gabinetes dos órgãos oficiais. A proposta visava oferecer às escolas públicas os subsídios necessários para a construção curricular, estimulando a descentralização do poder deliberativo sobre o currículo, a autonomia das escolas e a participação popular no movimento. Júlio do Valle (2019) analisa, na sua tese de doutorado, como se deu o movimento desde a sua proposição até a sua efetivação nas escolas, e fala da ênfase que Paulo Freire dá à Matemática, elucidando tanto suas potencialidades como também suas fragilidades.

A concessão do Prêmio Moinho Santista a Paulo Freire, juntamente com Celso Furtado, em 1995, foi memorável. Seu discurso de aceitação da premiação, falando também 
em nome de Celso Furtado, que mesmo estando presente, encontrava-se adoentado, foi uma grande aula sobre desenvolvimento, no sentido amplo, e sobre as desigualdades perniciosas que assolam nosso país, na verdade todos os países. Suas palavras iniciais, informais, foram marcantes. Numa forma de diálogo com Celso Furtado, falou das dificuldades de galgar uma carreira acadêmica. E, confiando em minha memória, eu me lembro de Paulo Freire ter dito algo como "Celso, nós representamos uma exceção dentre os brasileiros que buscam acesso. Conseguimos".

Um momento muito importante para a Educação Matemática foi o convite feito pela Comissão Organizadora do ICME-8 ( $8^{\circ}$ Congresso Internacional de Educação Matemática), a ser realizado em Sevilha, em 1996. Ele prontamente aceitou, o que criou grande expectativa dos Educadores Matemáticos de todo o mundo. Mas deu-se o imprevisto: o verão de 1996, em Sevilha, foi terrível e os médicos aconselharam Paulo Freire a não comparecer. De fato, fez um calor intolerável e esse foi um conselho muito prudente.

Em vista do imprevisto, a Comissão Organizadora do Congresso convidou o holandês Jan de Lange, destacado educador matemático, para fazer a conferência inaugural, mas comprometeu-se, mediante um substancial apoio da Casio Calculators, a projetar, repetidas vezes durante o decorrer do Congresso, um vídeo gravado por Paulo Freire especialmente para os participantes do Congresso. O vídeo foi gravado na forma de uma entrevista, e tive a honra de ser o entrevistador, o que foi prontamente aceito por ele, e a Professora Maria do Carmo Domite, sua grande amiga, discípula e colaboradora, atuou como mediadora ${ }^{1}$. Foi uma ocasião memorável. Fizemos a gravação na casa de Paulo Freire, e a projeção em Sevilha, repetidas vezes durante o Congresso, foi concorridíssima. A entrevista foi transcrita e publicada na forma de artigo, em Português e em Inglês, em conceituadas revistas internacionais. Esse evento foi, para mim, um grande momento pessoal e profissional.

Perguntado se existe um equivalente matemático à alfabetização na sua obra, Paulo Freire surpreendeu-se e confessou ter sido essa a primeira vez que lhe faziam essa pergunta tão diretamente, e disse que jamais havia pensado nisso. Prosseguiu, dizendo o que pensa que seja um ser humano matematizado. Não faço uma citação de sua entrevista, pois modifiquei um pouco sua argumentação. Mas reproduzo a essência da sua fala. Ele disse não ter dúvida nenhuma da importância de qualquer indivíduo, homem ou mulher, jovem ou adulto, trabalhador ou profissional, enfim, qualquer indivíduo, se reconhecer como corpos conscientes matematicizados. Disse não ter dúvida nenhuma de que a nossa presença no mundo implicou, indiscutivelmente, a invenção do mundo... Disse que tem pensado muito que

1 A transcrição da entrevista está disponível ao final deste editorial. 
o passo decisivo na nossa humanidade foi quando começou a se instalar a cultura, a linguagem, a invenção da linguagem, o pensamento que não apenas se atenta no objeto que está sendo pensado, mas que já se enriquece da possibilidade de comunicar e comunicar-se. Disse achar que, naquele momento, a gente se transformou também em matemáticos. A vida que vira existência se matematiza. Para mim, disse ele, eu acho que uma preocupação fundamental, não apenas dos matemáticos, mas de todos nós, sobretudo dos educadores, aos quais cabem certas decifrações do mundo, deveria ser a de propor aos jovens, estudantes, alunos homens do campo, que antes e ao mesmo em que descobrem que 4 por 4 são 16, descobrem, também, que há uma forma matemática de estar no mundo.

Paulo Freire contou que falava para os alunos que, quando a gente desperta, já caminhando para o banheiro, a gente já começa a fazer cálculos matemáticos. Disse que quando se olha o relógio, por exemplo, já estabelece a quantidade de minutos que se tem para, se acordou mais cedo, se acordou mais tarde, para saber exatamente a hora em que vai chegar à cozinha, que vai tomar o café da manhã, a hora que vai chegar o carro que vai nos transportar. Insistiu em dizer que, ao despertar, os primeiros movimentos, lá dentro do quarto, são movimentos matematicizados. Paulo Freire disse ser essa uma das preocupações, a de mostrar a naturalidade do exercício matemático.

A entrevista, na sua íntegra, revela a espontaneidade e o entusiasmo do grande educador. O acesso a essa entrevista, na íntegra, é fundamental para se entender o Paulo Freire pedagogo e sua especial atenção para a matemática. Repetidas vezes, Paulo Feire disse que o indivíduo deve se situar matematicamente no mundo, que é o objetivo essencial da etnomatemática. De fato, para Paulo Freire a matemática é tão fundamental quanto a alfabetização.

\section{O filósofo humanista}

Nunca fui discípulo de Paulo Freire. Como expliquei acima, só tardiamente vim a conhecê-lo, a ler suas obras e a dialogar e trocar ideias com ele. Esse encontro tardio foi marcante. Muito além de suas práticas pedagógicas, assimilei muito da sua postura intelectual e seu humanismo. Logo que conheci Paulo Freire e sua obra, reconheci nossa afinidade intelectual e convergência de pontos de vista. Sobretudo quando Paulo Freire diz que a missão do professor deve ser mais ouvir do que falar, entender o outro na sua espontaneidade.

A proposta de alfabetização de Paulo Freire e a prática pedagógica da etnomatemática são semelhantes. Essencialmente, é necessário falar menos e ouvir mais. Dar ao aluno, 
criança, jovem e adulto, a oportunidade de se expressar, com toda espontaneidade, sobre um tema, uma questão ou um problema, algo que o interesse e o afete. Assim, abrimos a possibilidade de o outro se reconhecer e, muitas vezes, recuperar sua dignidade reprimida, vilipendiada. Isto é, recuperar sua qualidade de ser humano.

Eu considero isso o mais importante para se entender Paulo Freire como um grande filósofo humanista. É a busca de um homem novo. Essas ideias permeiam toda sua obra.

Sua obra máxima é a Pedagogia do Oprimido. Acho que, logo no início, fica muito clara sua grandeza como filósofo humanista, muito mais importante que o pedagogo ou o ativista político.

Uma grande lição que aprendi de Paulo Freire, e que revela sua grande dimensão como humanista, está nas primeiras páginas da Pedagogia do Oprimido.

Não se trata de empoderar um ser humano oprimido, dando a ele os recursos intelectuais e materiais, para que ele se torne um outro opressor.

Cito o trecho que considero essencial, onde ele sintetiza suas ideias:

Isto decorre, como analisaremos mais adiante, com mais vagar, do fato de que, em certo momento de sua experiência existencial, os oprimidos assumam uma postura que chamamos de "aderência" ao opressor. Nestas circunstâncias, não chegam a "admirá-lo", o que os levaria a objetivá-lo, a descobri-lo fora de si. Ao fazermos esta afirmação, não queremos dizer que os oprimidos, neste caso, não se saibam oprimidos.

O seu conhecimento de si mesmos, como oprimidos, se encontra, contudo, prejudicado pela "imersão" em que se acham na realidade opressora. "Reconhecerse" a este nível, contrários ao outro, não significa ainda lutar pela superação da contradição. Daí esta quase aberração: um dos pólos da contradição pretendendo não a libertação, mas a identificação com o seu contrário.

O "homem novo", em tal caso, para os oprimidos, não é o homem a nascer da superação da contradição, com a transformação da velha situação concreta opressora, que cede seu lugar a uma nova, de libertação. Para eles, o novo homem são eles mesmos, tornando-se opressores de outros. A sua visão do homem novo é uma visão individualista. A sua aderência ao opressor não lhes possibilita a consciência de si como pessoa, nem a consciência de classe oprimida. Desta forma, por exemplo, querem a reforma agrária, não para libertar-se, mas para passar a ter terra e, com esta, tornar-se proprietários ou, mais precisamente, patrões de novos empregados. Raros são os camponeses que, ao serem "promovidos" a capatazes, não se tornam mais duros opressores de seus antigos companheiros do que o patrão mesmo. Poder-se-ia dizer - e com razão - que isto se deve ao fato de que a situação concreta, vigente, de opressão, não foi transformada. E que, nesta hipótese, o capataz, para assegurar seu posto, tem de encarnar, com mais dureza ainda, a dureza do patrão. Tal afirmação não nega a nossa - a de que, nestas circunstâncias, os oprimidos têm no opressor o seu testemunho de "homem".

Até as revoluções, que transformam a situação concreta de opressão em uma nova, em que a libertação se instaura como processo, enfrentam esta manifestação da consciência oprimida. Muitos dos oprimidos que, direta ou indiretamente, participaram da revolução, marcados pelos velhos mitos da estrutura anterior, pretendem fazer da revolução a sua revolução privada. Perdura neles, de certo modo, a sombra testemunhal do opressor antigo. Este continua a ser o seu testemunho de "humanidade" (FREIRE, 1987, p. 17-18). 
É a busca de um homem novo. A proposta de Paulo Freire é recuperar sua dignidade. Convergimos, integralmente, no nosso pensar: o grande objetivo é restabelecer a dignidade do ser humano e a construção de um homem novo, um outro modelo civilizatório, sem que haja opressores e oprimidos, mas todos seguindo uma ética de respeito, solidariedade e cooperação entre todos os seres humanos, reconhecendo as diferenças inevitáveis, próprias de uma espécie.

\section{Entrevista de Paulo Freire}

A entrevista com Paulo Freire foi exibida no ICME-8 que ocorreu em Sevilha/ Espanha, no ano de 1996. A entrevista teve como mediadora Maria do Carmo Domite e como entrevistador Ubiratan D'Ambrosio, tendo sido gravada, em 1996, na residência de Paulo Freire.

A gravação foi editada, traduzida para o inglês e projetada, repetidas vezes, sob o patrocínio da Casio Calculators, durante todo o ICME-8. Foi transcrita e publicada (FREIRE; D'AMBROSIO; MENDONÇA, 1997) com o título Conversation with Paulo Freire.

A publicação que se segue é uma transcrição literal e fiel, sem ajustes de linguagem, da gravação da entrevista.

MC - Estamos aqui reunidos para uma conversa, um bate papo informal, com o Professor Paulo Freire e o Professor Ubiratan D’Ambrosio, sobre educação e educação matemática.

U - Devo dizer que para mim é um privilégio raro poder entrevistar o mestre. Formalmente, nunca fui seu aluno, mas sou daquele exército de educadores do mundo inteiro que se consideram discípulos de Paulo Freire. Ter a oportunidade desta conversa é para mim uma grande honra.

P - Para mim também. Sobretudo compreendendo, como nós três aqui compreendemos, a continuidade desta conversa dentro de algum tempo mais na Espanha, diante de um grande número de matemáticos, de educadores que se metem com os problemas do ensino da matemática, da compreensão da matemática. Para mim também é uma grande satisfação estar nessa conversa e gostaria que ela até tomasse corpo imediatamente.

U - Hoje nós todos reconhecemos o Paulo Freire grande filósofo que inspira uma série de medidas novas em educação, propostas. É o nosso filósofo da educação. No início, há muitos anos, quando você começou a sua carreira, a sua grande preocupação parece ter sido, claro educação em geral, mas sempre se fala no Paulo Freire como ensinando, alfabetizando, 
ensinando a ler. Existe claro uma preocupação muito grande em todo seu discurso com a importância de o indivíduo se expressar, saber ler, participar do mundo. Eu pergunto: desde aquele momento até hoje, você vê uma importância equivalente em ele saber participar matematicamente do mundo. Você vê um equivalente ao literacy, uma forma de matheracy? Existe um equivalente matemático à alfabetização na sua obra?

$\mathrm{P}$ - Essa é uma pergunta primeira. É a primeira vez que eu me defronto com essa pergunta e eu acho que ela tem sentido. Tem sentido como uma pergunta não apenas feita a mim, mas feita a nós todos. Confesso que na época eu não pensei nisso. Não iria eu agora mentir e dizer ah, já naqueles anos, há quarenta anos atrás, eu já vivia pensando nisso. Não, na verdade eu não pensei nisso. Mas eu hoje entendo isso perfeitamente. Eu não tenho dúvida nenhuma da importância de qualquer esforço, que não deve inclusive ser um esforço exclusivo do matemático, professor de matemática por exemplo, mas que deveria ser no meu entender um esforço do homem e da mulher, matemático ou físico ou carpinteiro, que é exatamente o esforço de nos reconhecer como corpos conscientes matematicizados. Eu não tenho dúvida nenhuma de que a nossa presença no mundo, que implicou indiscutivelmente a invenção do mundo... Eu venho pensando muito que o passo decisivo que nos tornamos capazes de dar, mulheres e homens, foi exatamente o passo em que o suporte em que estávamos virou mundo e a vida que vivíamos virou existência, começou a virar existência. E que nessa passagem, nunca você diria uma fronteira geográfica para a história, mas nessa transição do suporte para o mundo e que se instala a história, é que começa a se instalar a cultura, a linguagem, a invenção da linguagem, o pensamento que não apenas se atenta no objeto que está sendo pensado, mas que já se enriquece da possibilidade de comunicar e comunicar-se. Eu acho que nesse momento a gente se transformou também em matemáticos. A vida que vira existência se matematiza. Para mim, e eu volto agora a esse ponto, eu acho que uma preocupação fundamental, não apenas dos matemáticos mas de todos nós, sobretudo dos educadores, a quem cabe certas decifrações do mundo, eu acho que uma das grandes preocupações deveria ser essa: a de propor aos jovens, estudantes, alunos homens do campo, que antes e ao mesmo em que descobrem que 4 por 4 são 16, descobrem também que há uma forma matemática de estar no mundo. Eu dizia outro dia aos alunos que quando a gente desperta, já caminhando para o banheiro, a gente já começa a fazer cálculos matemáticos. Quando a gente olha o relógio, por exemplo, a gente já estabelece a quantidade de minutos que a gente tem para, se acordou mais cedo, se acordou mais tarde, para saber exatamente a hora em que vai chegar à cozinha, que vai tomar o café da manhã, a hora que vai chegar o carro que vai nos levar ao seminário, para chegar às oito. Quer dizer, ao despertar os primeiros movimentos, lá dentro do 
quarto, são movimentos matematicizados. Para mim essa deveria ser uma das preocupações, a de mostrar a naturalidade do exercício matemático. Lamentavelmente, o que a gente vem fazendo, e eu sou um brasileiro que paga, paga caro... Eu não tenho dúvida nenhuma que dentro de mim há escondido um matemático que não teve chance de acordar, e eu vou morrer sem ter despertado esse matemático, que talvez pudesse ter sido bom. Bem, uma coisa eu acho, que se esse matemático que existe dormindo em mim tivesse despertado, de uma coisa eu estou certo, ele seria um bom professor de matemática. Mas não houve isso, não ocorreu, e eu pago hoje muito caro, porque na minha geração de brasileiras e brasileiros lá no Nordeste, quando a gente falava em matemática, era um negócio para deuses ou gênios. Se fazia uma concessão para o sujeito genial que podia fazer matemática sem ser deus. E com isso, quantas inteligências críticas, quantas curiosidades, quantos indagadores, quanta capacidade abstrativa para poder ser concreta, perdemos. Eu acho que nesse congresso, uma das coisas que eu faria era, não um apelo, mas eu diria aos congressistas, professores de matemática de várias partes do mundo, que ao mesmo tempo em que ensinam que 4 vezes 4 são 16 ou raiz quadrada e isso e aquilo outro, despertem os alunos para que se assumam como matemáticos.

U - Em todo o seu discurso, a sua teorização, a sua prática, se vê a importância política da aquisição da linguagem. Você diz que o homem para ser livre tem que ser capaz de se expressar, tem que ser capaz de ler, ser capaz de discursar. Você vê alguma coisa equivalente no domínio da matemática?

P - Eu acho que indiscutivelmente essa possível alfabetização da matemática, uma matealfabetização, math-literacy, eu não tenho dúvida nenhuma que isso ajudaria a própria criação da cidadania. E vou dizer como eu vejo, e não como se deve ver. Eu falo como eu vejo. Eu acho que no momento em que você traduz a naturalidade da matemática como uma condição de estar no mundo, você trabalha contra um certo elitismo com que os estudos matemáticos, mesmo contra a vontade de alguns matemáticos, têm. Quer dizer, você democratiza a possibilidade da naturalidade da matemática, e isso é cidadania. E quando você viabiliza a convivência com a matemática, não há dúvida que você ajuda a solução de inúmeras questões que ficam aí às vezes entulhadas, precisamente por falta de um mínimo de competência sobre a matéria. E porque não está havendo isso? Porque a compreensão da matemática virou uma coisa profundamente refinada, quando na verdade não é e não deveria ser. Eu não quero com isso dizer que os estudos matemáticos jamais devessem ter a profundidade e a rigorosidade que eles têm que ter. Como o filosofo tem também que ser rigoroso, o biólogo, não é isso que eu digo. Mas o que eu digo é o seguinte: na medida em que você não faz simplismo, mas torna simples, a compreensão da existência matemática da existência humana, aí não há 
dúvida nenhuma que você perceberá a importância dessa compreensão matemática, tão grande quanto a linguagem.

MC - Essa é a matemática natural, a matemática que fala da quantificação natural. Então o menino pequeno tem alguma coisa a falar, por exemplo sobre a multiplicação como ele entende, e o professor não vê isso como sendo válido. É uma outra visão de matemática.

P - Isso não se dá apenas com a matemática, isso se dá com a presença do homem e da mulher no mundo. Eu acho que tem muito que ver com um certo desprestígio do senso comum. Isso tem muito que ver com a postura elitista da escola, relegando toda a contribuição que o aluno possa dar à escola. No fundo, é a super-valoração do conhecimento chamado acadêmico diante da desvalorização do conhecimento comum. É a posição epistemológica segundo a qual entre um e outro conhecimento você tem uma definitiva ruptura. No meu entender o que há não é uma ruptura, o que há é uma superação. Uma das coisas que a escola deveria fazer, e eu venho insistindo nisso há 30 anos ou mais, e fui muito mal-entendido, e ainda hoje continuo a ser, mas no começo fui muito menos entendido, quando eu insistia que o ponto de partida da prática educativa deve ser não a compreensão do mundo que tem o educador e o seu sistema de conhecimento, mas a compreensão do mundo que tem, ou que esteja tendo, o educando. A gente parte do que o educando sabe para que o educando possa saber melhor, saber mais e saber o que ainda não sabe. Eu acho que está nesse desrespeito, que é um desrespeito elitista, está na superação desse desrespeito, está no aprofundamento de uma postura democrática, eu acho a superação desse ser.

MC - É um elemento de ordem epistemológica querer que o aluno conheça melhor, mas é um desrespeito.

$\mathrm{U}-\mathrm{O}$ aluno vai para a escola para receber.

$\mathrm{P}-\mathrm{E}$ isso, e ele inclusive está convencido disso.

U - Para levar adiante essa nova postura pedagógica é necessário mudar o professor. A maneira como o professor tem sido formado tem sido fundamental, e eu sei que um dos seus projetos atuais é escrever um livro sobre formação de professores. Daria para falar um pouco sobre isso, de uma forma mais dirigida à nossa preocupação, como educadores matemáticos? Como a formação de professores deve ser revitalizada nesse seu pensamento?

$P$ - Eu estou realmente escrevendo um livro agora, que eu espero não seja nem um caderno nem um compêndio, um livro à minha maneira. O título provisório do livro vai ser formação docente e saberes necessários fundamentais à prática educativa crítica. A minha preocupação ao estar escrevendo esse livro é mostrar, às vezes até mais do que saberes, mostrar certas sabedorias indispensáveis a um professor, ou à formação do educador. Por exemplo, talvez o 
primeiro saber que deve virar uma sabedoria e que exatamente a gente incorpora é o seguinte: a prática educativa se funda não apenas na inconclusão ontológica do ser humano, mas na consciência da inconclusão. É em cima desses dois pés, de um lado a minha inconclusão, do outro a minha consciência da inconclusão, é aí que se funda a educação. A educabilidade humana não tem outra explicação senão nesta assunção de minha inconclusão consciente. Como também é ai que se fundamenta a minha esperança. Você imagine que incongruência seria que ser inconclusos como somos e conscientes da inconclusão, não nos lançássemos num permanente movimento de procura, de busca. O ser que não procura é aquele que sendo inconcluso não se sabe inconcluso. Exemplo: a jaboticabeira que eu tenho no quintal da casa é inconclusa também, porque o fenômeno da inconclusão é um fenômeno vital, não é exclusivo do ser humano. Mas o nível de inconclusão da jaboticabeira não tem nada a ver com meu nível de inconclusão. Ela é inconclusa, como é inconcluso meu pastor alemão no quintal, mas eles não se sabem inconclusos. No caso da gente, a gente assumiu a inconclusão e ao assumir a inconclusão, a gente é levada à busca. Seria um absurdo buscar sem esperança. Eu posso até ao buscar não encontrar, mas a minha esperança faz parte do processo de buscar. Não há busca desesperançada. É um contra-senso. Esse saber ... nem sempre os educadores foram um dia desafiados para saber-se interminados. Eu estou escrevendo sobre isso. Um outro saber, que eu acho que é uma sabedoria já, sem a qual não dá para ir para uma escola, é o saber de que mudar é difícil, mas é possível. Como é, Ubiratan, que tu poderias andarilhar pelo mundo como tu andas, na África, na Europa, nos Estados Unidos, discutindo o que é a matemática e discutindo como propor a matemática, se tu não estivesses convencido que um dia pode mudar. É o impulso. Esse saber precisa ser discutido, não imposto, mas tem que ser posto em cima da mesa, para que o jovem que está se formando para ser professor amanhã, repouse nesta verdade: eu me movo como professor porque apesar de saber quão difícil é mudar, eu sei que é possível mudar. Pode ser até que o agente da mudança mais radical não seja nem sequer minha geração, mas sem a minha geração a outra não vai mudar.

U - Nós trabalhamos para um outro futuro, no qual nós acreditamos.

$\mathrm{P}$ - Exato. Um outro saber que eu preciso saber é que ensinar não é transferir conhecimento, transferir conteúdo. É lutar para com os alunos, criar as condições para que o conhecimento seja construído, seja reconstruído. Isso para mim é que é ensinar. Enquanto eu não estiver convencido disso, enquanto eu estiver pelo contrário convencido que ensinar é chegar às nove horas da manhã e despejar um discurso transferidor de objetos, e que são apenas perfis de objetos, que são os conteúdos, então eu não sei o que é ensinar, eu não sei o que é aprender. É preciso que eu, como professor, saiba que do ponto de vista histórico, o homem e a mulher 
primeiro aprenderam, para depois ensinar. $\mathrm{O}$ aprender precedeu sempre o ensinar. $\mathrm{O}$ que é que está acontecendo na sistemática da escola? O ensinar virou o mais importante, e o aprender foi burocratizado com a burocratização do ensinar. Na verdade, o que eu não posso é deixar de conhecer os dois em processo contraditório dialético, em que quanto melhor eu aprendo tanto melhor eu posso ensinar e quanto mais eu ensinar tanto melhor se pode aprender. Mas foi aprendendo socialmente que historicamente as mulheres e os homens descobriram no ato de aprender diluída a prática de ensinar. Um dia na história dos homens e das mulheres, um dia mais ou menos recente, é que descobriram que porque aprendiam era possível ensinar, e aí se sistematizou o trabalho de ensino. A gente perdeu essa noção da história e inverteu os papéis. Eu também estou escrevendo sobre isso. Eu acho que às vezes é preciso recuperar historicamente o grande papel de aprender, sem que isso signifique nenhuma diminuição do ensinar.

$\mathrm{U}$ - A escola deve ser um ambiente, ser tornado um ambiente mais para compartilhar esse processo de busca, e não um ambiente onde se passa conhecimento.

P - Claro. Poderia se pensar que eu estou defendendo aqui um papel subalterno para o professor. De jeito nenhum. Indiscutivelmente o papel do professor, o papel do ensinante, é um grande papel. Ele/ela tem uma grande responsabilidade de ensinar. E professor que não ensina não se justifica, ele não se explica a si mesmo. Agora, é preciso clarear e esclarecer o que significa mesmo ensinar. E quando a gente busca compreender na própria prática o que é ensinar, a gente tem que concluir que o próprio esforço do processo social da produção do conhecimento põe de lado qualquer possibilidade de transferir conhecimento. Eu produzo, eu crio, eu recrio o conhecimento, eu não engulo conhecimento. Eu me lembro de uma expressão irônica de Sartre, quando ele criticava o que ele chamava de concepção nutricionista do saber. Ele diz: trágica e dolorosa a concepção nutricionista do saber, em que o professor alimenta, e você vê as metáforas todas que a gente vê na linguagem comum para nos referir ao problema do conhecimento. Tem muito a ver com alimento. Você fala de fome de saber, sede de saber. Você não fala na curiosidade de saber. Você fala na sede do saber. Eu não tenho que beber saber, nem tenho que comer saber. Eu como uma feijoada, não conhecimento. Conhecimento eu produzo socialmente.

U - A ideia da produção do conhecimento, sobretudo em matemática, parece que ficou muito esquecida.

$\mathrm{P}$ - Muito, muito, muito.

$\mathrm{U}$ - Se produz muito pouco no sistema escolar. Eu acho que essa oportunidade desse papo com Paulo Freire foi realmente um momento muito importante para todos nós, e esses do 
congresso que nos assistem vão sentir aquela pontinha de inveja, porque nós tivemos o privilégio dessa conversa com o Paulo.

$\mathrm{P}$ - Eu quero mandar através de vocês que estarão lá, o meu grande abraço a todos e a todas que vão comparecer ao congresso e lhes dizer que minha ausência só se poderia explicar mesmo por uma questão de cuidados que eu e meus médicos estão tendo. Eles estão fazendo força, e eu concordo com o esforço deles, no sentido de ver se eu demoro um pouco mais no mundo. E com isso eu concluo.

MC - Gostaria também de agradecer estar com o senhor. Quando o professor Ubiratan começou dizendo que todos nós fomos, de algum modo, alunos de Paulo Freire, é verdade, mas nem todos conseguiram entender. Porque cada vez tem uma coisa nova. A gente está sempre aprendendo coisas novas. Os dois representam para nós uma mudança de modelo. $\mathrm{O}$ senhor, em geral, em educação, e o professor Ubiratan D’Ambrosio em educação matemática. P - Com o D'Ambrosio você extrapola o adjetivo matemático e pode ficar só na educação mesmo. Eu acho que D'Ambrosio é na verdade até mais que um educador, ele é também um pensador da educação atual. Agora eu peço desculpas para vocês e eu vou correndo para o doutor.

\section{Referências}

FREIRE, P. Educação e Atualidade Brasileira. 1959. Tese de Concurso para cadeira de História e Filosofia da Educação - Escola de Belas Artes de Pernambuco, Recife, 1959.

FREIRE, P. Cartas à Guiné-Bissau: registros de uma experiência em Processo. 2. ed. Rio de Janeiro, Paz e Terra, 1978.

FREIRE, P. Pedagogia do oprimido. 17. ed. Rio de Janeiro: Paz e Terra, 1987.

FREIRE, P.; D'AMBROSIO, U.; MENDONÇA, M. A Conversation with Paulo Freire. For the Learning of Mathematics, Canadá, v. 17, n. 3, p. 7-10, nov. 1997. Disponível em: http://www.jstor.org/stable/40248246. Acesso em 13 mar. 2021.

VALLE, J. C. A. do. Inversão do vetor nas políticas curriculares: O Movimento de Reorientação Curricular de Freire em São Paulo (1989-1992). 2019. 326 f. Tese (Doutorado em Educação) Faculdade de Educação, Universidade de São Paulo, São Paulo, 2019. 